\title{
Identification of hearing loss relevant genes in QTL on mouse chromosome 16
}

\author{
Fusheng Zhao ${ }^{1,2}$, Yonghui Ma' ${ }^{1}$, Yan Jiao ${ }^{1}$, Lishi Wang ${ }^{1}$, Yue Huang ${ }^{1}$, Wei Wei ${ }^{1}$, Weikuan Gu ${ }^{1 *}$ \\ From 11th Annual UT-ORNL-KBRIN Bioinformatics Summit 2012 \\ Louisville, KY, USA. 30 March - 1 April 2012
}

\section{Background}

Previously, a quantitative trait loci (QTL) for hearing loss on chromosome 16 in a 118 TNE and CAST background has been identified. The overlap of two of interval specific congenic recombinant strains (ISCRS) strains reduced the QTL interval into a 5,378,407 bps genome region.

\section{Results}

By examining the genomic information of the QTL on chromosome 16, between the two flanking markers, D16mit191 and D16mit86, we identified a total of 84 genetic elements in the 5,378,407 bps genome region. Among these genetic elements, we found seven with potential function in hearing loss preference (Table 1). We then examined the SNPs, insertions and deletions, and gene expression levels of those seven genes.

\section{Conclusions}

Our current data suggest that the Kcne1 and Sod1 genes are potentially the most hearing loss relevant genes.
However, further experiments and examination are still needed to confirm their candidacy. Several other candidate genes are also in the process of being identified.

\section{Acknowledgments}

Support for this research is partially from the NIAAA (1R01 AA016342), NIH, the Veterans Administration Medical Center, and DNA Discovery Core, University of Tennessee, Memphis, Tennessee.

\section{Author details}

'Department of Orthopedic Surgery-Campbell Clinic and Pathology, University of Tennessee Health Science Center, Memphis, TN 38163, USA. ${ }^{2}$ Department of Histology and Embryology, Mudanjiang Medical College, Mudanjiang, PR China.

Published: 31 July 2012

doi:10.1186/1471-2105-13-S12-A8

Cite this article as: Zhao et al:: Identification of hearing loss relevant genes in QTL on mouse chromosome 16. BMC Bioinformatics 201213 (Suppl 12):A8.

Table 1 Candidate genes for hearing loss on Chr 16

\begin{tabular}{lll}
\hline Ensembl Accession & Symbol & Full Name \\
\hline ENSMUSG00000039639 & Kcne1 & potassium voltage-gated channel \\
ENSMUSG00000022949 & CLIC6 & Chloride intracellular channel 6 \\
ENSMUSG00000022952 & RUNX1 & Runt-related transcription factor 1 \\
ENSMUSG00000079514 & SLC5A3 & Sodium/myo-inositol cotransporter \\
ENSMUSG00000022982 & Sod1 & superoxide dismutase 1 \\
ENSMUST00000047383 & Kcne2 & potassium voltage-gated channel \\
ENSMUSG00000022967 & Ifnar1 & interferon (alpha and beta) receptor 1
\end{tabular}

\footnotetext{
* Correspondence: wgu@uthsc.edu

'Department of Orthopedic Surgery-Campbell Clinic and Pathology, University of Tennessee Health Science Center, Memphis, TN 38163, USA
} Full list of author information is available at the end of the article

Submit your next manuscript to BioMed Central and take full advantage of:

- Convenient online submission

- Thorough peer review

- No space constraints or color figure charges

- Immediate publication on acceptance

- Inclusion in PubMed, CAS, Scopus and Google Scholar

- Research which is freely available for redistribution

Submit your manuscript at www.biomedcentral.com/submit

\section{() Biomed Central}

\section{Biomed Central}

